\title{
Cytokine mRNA expression in the mucosa of treated coeliac patients after wheat peptide challenge
}

\author{
M Kontakou, R T Przemioslo, R P Sturgess, G A Limb, H J Ellis, P Day, P J Ciclitira
}

\begin{abstract}
This study investigated the presence of mRNA coding for interferon gamma (IFN $\gamma$ ), tumour necrosis factor alpha $(T N F \alpha)$, and interleukins 2 (IL2) and 6 (IL6), in the mucosa of four coeliac patients in remission who had been challenged with either gliadin or synthetic gliadin oligopeptides. Jejunal biopsy specimens from these patients, taken before and at two, four, and six hours after challenge, were hybridised with specific ${ }^{35}$ S-labelled DNA oligonucleotide probes. The lamina propria of all the patients contained significantly increased numbers of cytokine mRNA expressing cells four hours after challenge with gliadin or an oligopeptide corresponding to amino acids 31-49 of A-gliadin (peptide A). No significant changes were seen with the peptides corresponding to aminoacids 202-220 (peptide B) or 3-21 (peptide C) of Agliadin, with the exception of one patient who showed a significant increase in the number of TNF $\alpha$ mRNA expressing cells four hours after challenge with peptide $B$. In vivo studies in coeliac disease have shown that significant histological changes occur in the mucosa of treated coeliac patients four hours after challenge with either gliadin or peptide $A$. These findings suggest that the histological changes seen previously in the mucosa of coeliac patients after wheat peptide challenge may be caused by increased expression of cytokines within the mucosa.

(Gut 1995; 37: 52-57)
\end{abstract}

Keywords: coeliac disease, wheat peptide, mRNA expression.

Coeliac disease is a gluten induced enteropathy. The small intestinal mucosa of affected subjects exhibits crypt cell hyperplasia and villous flattening ${ }^{1}$ and the lamina propria is infiltrated with lymphocytes, macrophages, and plasma cells. ${ }^{2-4}$ These changes revert towards normal on removal of gluten from the diet.

The condition is thought to represent an abnormal immune response in genetically susceptible subjects, to the ingestion of certain cereal peptides, which remain unidentified. The causative agent in wheat is in the ethanol soluble prolamin fraction, gliadin, whose toxicity remains after peptic-tryptic digestion. ${ }^{5}$ We have previously synthesised three peptides corresponding to amino acids 3-21, 31-49, and $202-220$ of A-gliadin whose coeliac toxicity is supported by earlier in vitro studies. ${ }^{67}$ These peptides and gliadin were used to challenge four coeliac patients in remission. ${ }^{8}$ Jejunal biopsy specimens were taken before and at hourly intervals for six hours after the infusions. Morphometric measurements and intraepithelial lymphocyte counts have shown that gliadin and the oligopeptide whose sequence corresponds to amino acids 31-49 of A-gliadin are both toxic in vivo within four hours of challenge but there was no evidence of toxicity of the peptide with residues 3-21. Evidence from two previous in vivo studies using the peptide $202-220$ is equivocal ${ }^{89}$ and suggests that this peptide may contain an epitope to which coeliac patients display variable sensitivity.

It was suggested that the observed morphological changes may be caused by immune activation with the intestinal mucosa. Previous studies have shown induced activation (that is, CD25 expression) of lamina propria $\mathrm{CD}^{+} \mathrm{T}$ cells and macrophages in coeliac mucosa after in vitro stimulation with gluten. ${ }^{10}$ These activated cells are capable of producing cytokines, which are important mediators of intestinal inflammation. ${ }^{11-14}$

In this study we have investigated the mRNA expression of two $T$ cell derived cytokines, interferon gamma (IFN $\gamma$ ) and interleukin 2 (IL2), and two cytokines secreted predominantly from macrophages, tumour necrosis factor alpha (TNF $\alpha)$ and interleukin 6 (IL6), in the mucosa of treated coeliac patients after in vivo challenge with the wheat peptides described above.

\section{Methods}

\section{Patients}

The patient group studied consisted of four unrelated white patients with coeliac disease, diagnosed according to the previous ESPGAN criteria. ${ }^{15}$ The mean age of the patients was 49.5 years (range 29-76) and the mean number of years receiving a gluten free diet was

TABLE I Oligopeptides used in the study, where the numbers represent residues within the 266 aminoacid, $A$-gliadin protein. From Sturgess et $\mathrm{al}^{8}$

\begin{tabular}{lcl}
\hline Peptide & $\begin{array}{c}\text { A-gliadin } \\
\text { homology }\end{array}$ & Sequence \\
\hline A & $31-49$ & LGQQQPFPPQQPYPQPQPF \\
B & $202-220$ & QQYPLGQGSFRPSQQNPQA \\
C & $3-21$ & VPVPQLQPQNPSQQQPQEQ \\
\hline
\end{tabular}

Gastroenterology Unit, 
TABLE II DNA sequence of oligonucleotides used in this study

\begin{tabular}{ll}
\hline IFN $\gamma .1$ & 5' AAA GAG TTC CAT TAT CCG CTA CAT TCG AAT 3' \\
IFN $\gamma .2$ & 5' GTA TTG CTT TGC GTT GGA CAT TCA AGT CAG 3' \\
IFN $\gamma .3$ & 5' ACC CAA AAC GAT GCA GAG CTG AAA AGC CAA 3' \\
TNF $\alpha .1$ & 5' GCT GGG CTC CGT GTC TCA AGG AAG TCT GGA 3' \\
TNF $\alpha .2$ & 5' CGG GGT TCG AGA AGA TGA TCT GAC TGC CTG 3' \\
TNF $\alpha .3$ & 5' AGT AGG CCG ATT ACA GAC ACA ACT CCC TGG 3' \\
IL6.1 & 5' GCA TTT GTG GTT GGG TCA GGG GTG GTT ATT 3' \\
IL6.2 & 5' CTG CCT CTT TGC TGC TTT CAC ACA TGT TAC 3' \\
IL6.3 & 5' CAT CTG GAC AGC TCT GGC TTG TTC CTC ACT 3' \\
IL2.1 & 5' AAC TTA AAT GTG AGC ATC CTG GTG AGT TTG 3' \\
IL2.2 & 5' GCT AAA TTT AGC ACT TCC TCC AGA GGT TTG 3' \\
IL2.3 & 5' AGA CTT AGT GCA ATG CAA GAC AGG AGT TGC 3' \\
\hline
\end{tabular}

13.3 years (range 2-24). Patients gave their written informed consent to the study, which was approved by the St Thomas' Hospital ethics committee.

\section{Challenges and biopsies}

Oligopeptides (Table 1) were synthesised with a solid phase peptide synthesiser and analysed for purity and amino acid sequence as described earlier. ${ }^{8}$ Each patient had four challenges: gliadin first $(1 \mathrm{~g})$, followed by the peptides $(200 \mathrm{mg}$ ) in random order, with at least one week between to permit recovery of the jejunal mucosa. The challenge and biopsy procedure has been described previously. ${ }^{8}$ Tissue specimens taken before and at two, four, and six hours after each challenge were immediately orientated, embedded in optimal cutting temperature compound (Cryo-M-bed; Bright's, Huntington, UK), snap frozen in liquid nitrogen cooled isopentane, and stored in liquid nitrogen until processed. Cryostat sections were cut at $5 \mu \mathrm{m}$ on a Bright's open top cryostat at $-20^{\circ} \mathrm{C}$ and collected onto glass slides that had been washed with distilled water rendered RNase free by diethylpyrocarbonate (DEPC) treatment ${ }^{16}$ and precoated with polyL-lysine. Sections were briefly fixed in acetone for five minutes and stored at $-20^{\circ} \mathrm{C}$.

\section{Probes and labelling method}

DNA oligonucleotide probes were prepared 'in

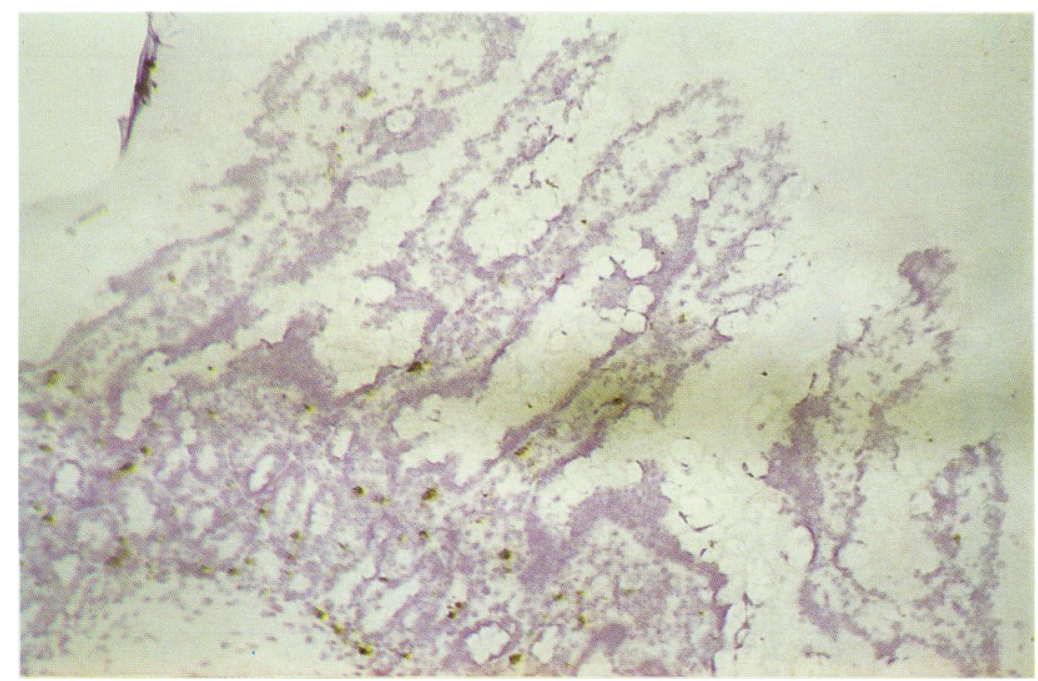

Figure 1: Fejunal biopsy specimen from a patient with coeliac disease in remission (patient 4) before gliadin challenge, showing the distribution of cells expressing $m R N A$ for TNF $\alpha$ $(\times 200$ magnification). house' using a Beckman synthesiser. Cytokine detection was achieved using a cocktail of three probes for each cytokine, each 30 bases long, with cDNA sequences coded by three different exon regions of the IFN $\gamma$, TNF $\alpha$, IL6, and IL2 genes. Table II lists the probes used in this study and their sequences.

Four pmol of each oligonucleotide were labelled by the addition of an $\alpha^{35} \mathrm{~S}$ dATP 'tail' to the $3^{\prime}$ termini using terminal deoxynucleotidyl transferase, according to the supplier's protocol (Promega). After the labelling reaction, probes were purified by filtration through Sephadex G-50 DNA grade columns (Pharmacia) and their specific activity measured using a Rackbeta liquid scintillation counter. The specific activity of the probes was greater than $1 \times 10^{8} \mathrm{cpm} / \mu \mathrm{g}$.

\section{Probe specificity}

Specificity of the probes was confirmed by northern blotting of mRNA coding for IFN $\gamma$, $\mathrm{TNF} \alpha$, IL6, and IL2, isolated from blood mononuclear cells that had been cultured in the presence of $1 \mu \mathrm{g} / \mathrm{ml}$ phytohaemagglutinin (PHA) or $10 \mu \mathrm{g} / \mathrm{ml}$ concanavalin A (Con A) as previously described. ${ }^{17}$ The sequences of the probes were compared with known genomic sequences by computer analysis using the DNASIS program. Northern blot analysis also determined their ability to hybridise to complementary mRNA. The reactivity of the probes was tested by in situ hybridisation of mononuclear cells activated with the above mitogens.

\section{Pretreatment and hybridisation}

The method used was a modification of that previously described by Hamid et al. ${ }^{18}$ All solutions used were prepared with DEPC treated water. Fixation: $4 \%$ (w/v) paraformaldehyde (PFA) in phosphate buffered saline (PBS) $\mathrm{pH}$ $7 \cdot 4$ for 15 minutes, followed by two washes in $15 \%(\mathrm{w} / \mathrm{v})$ sucrose in PBS for 10 minutes each. Pretreatments: (a) $0.3 \%$ (v/v) Triton-X-100 in PBS for 10 minutes, (b) $1 \mu \mathrm{g} / \mathrm{ml}$ proteinase $\mathrm{K}$ for 30 minutes at $37^{\circ} \mathrm{C}$, (c) postfixation in $0.4 \%$ (w/v) PFA for 10 minutes, and (d) $0.1 \mathrm{M}$ triethanolamine containing $0 \cdot 25 \%(\mathrm{v} / \mathrm{v})$ acetic anhydride for 10 minutes. Sections were prehybridised in a mixture of $2 \times$ saline-sodium citrate buffer (SSC), $50 \%(\mathrm{v} / \mathrm{v})$ formamide and $1 \times$ Denhardt's solution at $37^{\circ} \mathrm{C}$ for one hour and then hybridised overnight with $2 \mathrm{ng}$ of labelled probe at $37^{\circ} \mathrm{C}$ in a solution containing: $2 \times$ SSC, $50 \%(\mathrm{v} / \mathrm{v})$ formamide, $0.4 \mathrm{mg} / \mathrm{ml}$ denatured sheared salmon sperm DNA, and $10 \%(\mathrm{w} / \mathrm{v})$ dextran sulphate. Posthybridisation washes were carried out at $39^{\circ} \mathrm{C}$, for 30 minutes each, in $2 \times S S C, 1 \times S S C+50 \%$ formamide, and $0 \cdot 1 \times$ SSC. Sections were dehydrated serially in $60 \%, 90 \%$, and $95 \%$ ethanol and dried at room temperature. For autoradiography, sections were dipped in Ilford $\mathrm{K} 5$ photographic gel emulsion that had been diluted $1: 1$ in prewarmed distilled water. The sections were left to dry in a dark room for about two hours and then incubated at $4^{\circ} \mathrm{C}$ in 


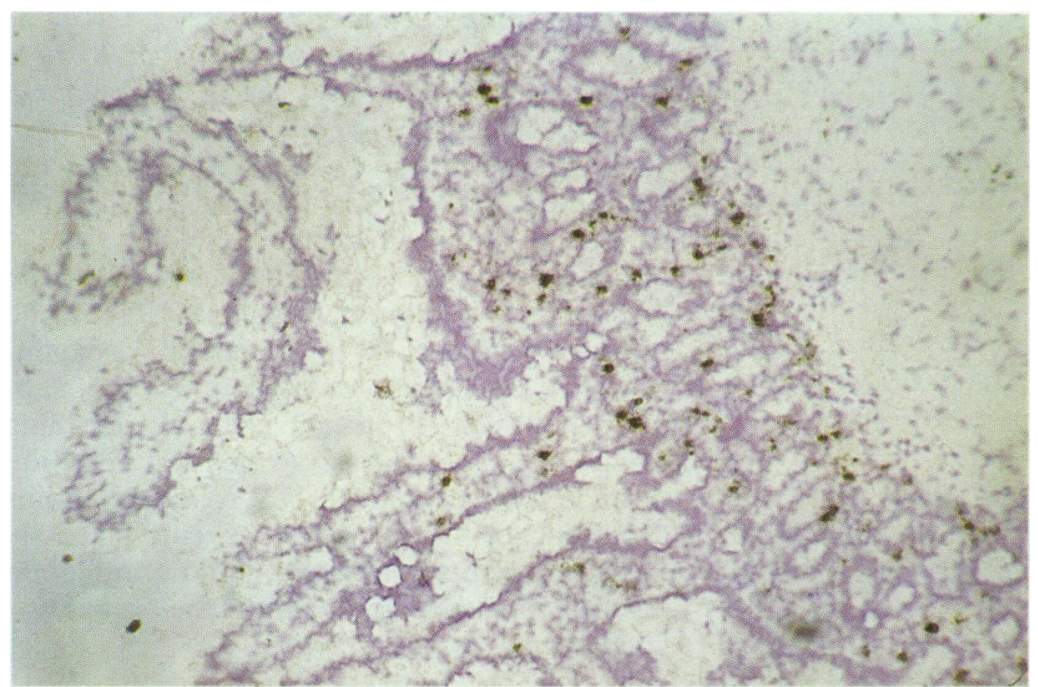

Figure 2: Distribution of TNF $\alpha$ mRA expressing cells in the jejunal mucosa of patient 4, four hours after gliadin challenge ( $\times 200$ magnification).

a light proof box containing silica gel for five days. Slides were developed in $4.4 \%(w / v)$ Dektol solution (Kodak) for two minutes, washed briefly in distilled water, and fixed in $30 \%(w / v)$ sodium thiosulphate at $4^{\circ} \mathrm{C}$ for 5 minutes. Finally the slides were thoroughly rinsed in running tap water and counterstained with Mayer's haematoxylin.

\section{Controls}

Treatment of slides with either RNase free DNase (no effect on hybridisation) or DNase free RNase (no hybridisation) were used as negative controls. After the proteinase $\mathrm{K}$ treatment, sections were incubated at $37^{\circ} \mathrm{C}$ with either of the two enzymes at a concentration of $100 \mu \mathrm{g} / \mathrm{ml}$ for 30 minutes. DNA oligonucleotides with sense sequences complementary to IFN $\gamma .1$, TNF $\alpha .1$, IL6.1, and IL2.1 anti-sense probes (Table II), were used as negative controls. As a positive control, an oligo dT probe was used for the detection of total mRNA.

\section{Quantification and statistical analysis}

All assessments were performed blind to patient identity and peptide. The number of positive cells within the lamina propria were counted per unit area by using an eyepiece graticule $\left(1 \mathrm{~mm}^{2}\right)$ under $\times 400$ magnification. At least five consecutive areas in the lamina propria, within and below the villi going to the deeper lamina propria were counted for each probe. Counts were expressed as positive cells in the lamina propria per unit area $(0.0025$ $\mathrm{mm}^{2}$ ) and referred to in the text as median (range). For each patient, the Wilcoxon rank sum test for unpaired data was used to compare the values at each time point after the challenge with those obtained before the challenge. Significance was set at $\mathrm{p}<0.05$.

\section{Results}

Figure 1 shows the distribution of $\mathrm{TNF} \alpha$ mRNA expressing cells within the jejunal mucosa before the gliadin challenge and Fig 2
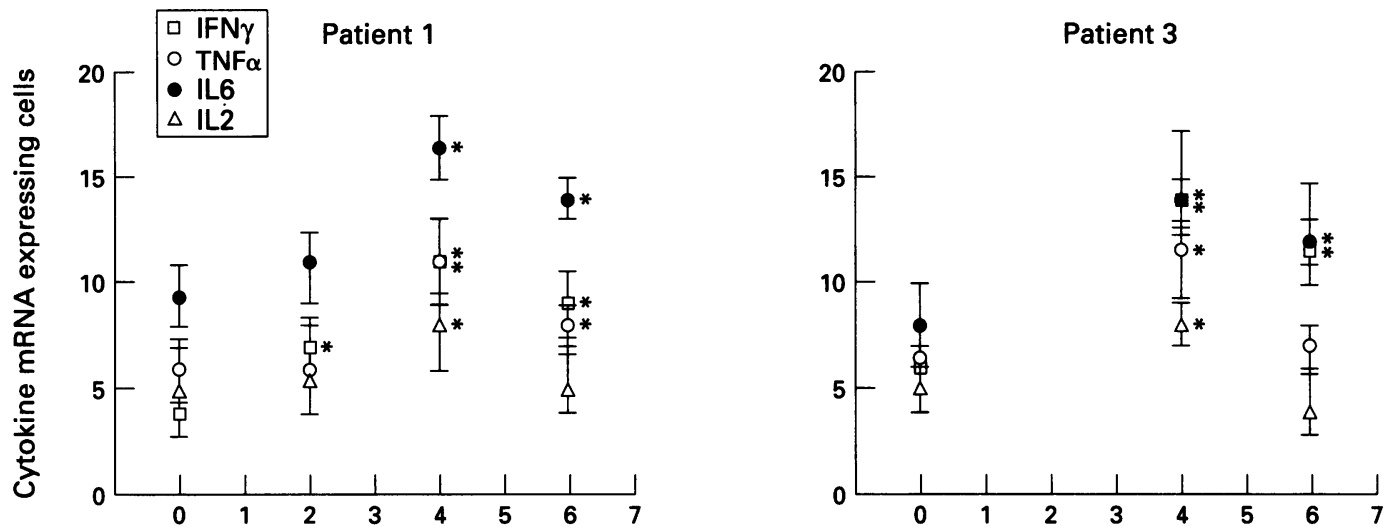

Patient 2

Patient 4
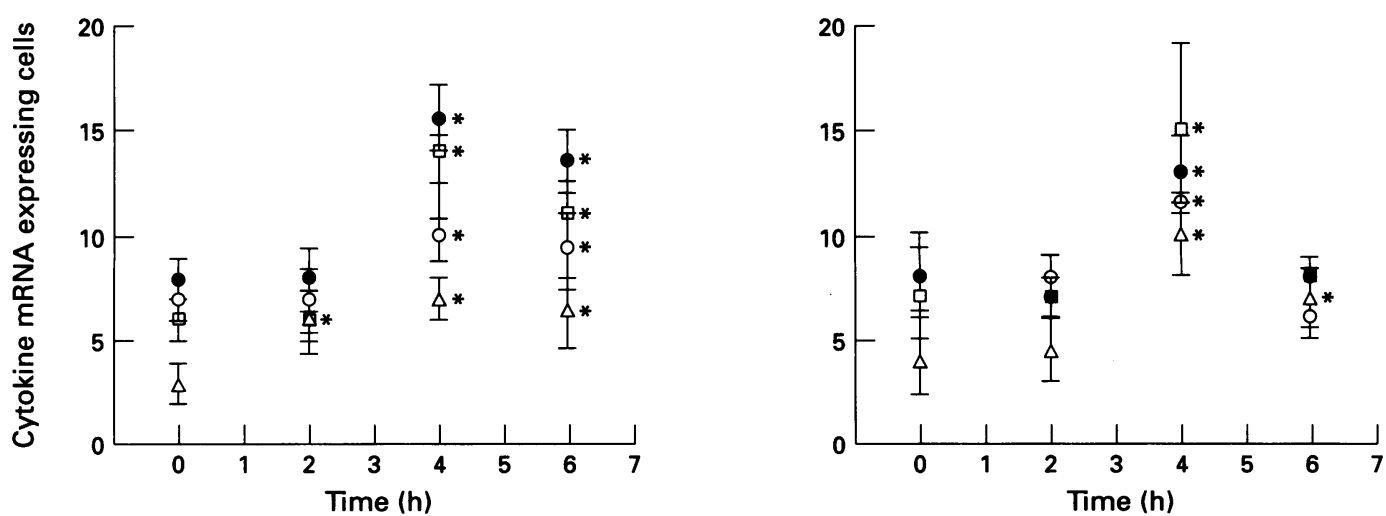

Figure 3: Median numbers (range) of cytokine mRNA expressing cells in the lamina propria of each patient (per $0.0025 \mathrm{~mm}^{2}$ ), before and at different time points after gliadin challenge. ${ }^{\star} p<0.05$ (compared with time 0 hours). 
TABLE III Median numbers of positive cells per unit area of the lamina propria/0.0025 $\mathrm{mm}^{2}$ before challenge (time 0) and four hours after challenge with the oligopeptides. The range of results obtained is shown in brackets

\begin{tabular}{|c|c|c|c|c|}
\hline \multirow[b]{2}{*}{ Time (h) } & \multicolumn{4}{|c|}{ Cytokine $m R N A+v e$ cells } \\
\hline & $I F N \gamma$ & $T N F \alpha$ & IL6 & $I L 2$ \\
\hline \multicolumn{5}{|l|}{$\begin{array}{l}\text { Patient 1 } \\
\text { Peptide A: }\end{array}$} \\
\hline $\begin{array}{l}0 \\
4\end{array}$ & $\begin{array}{l}5 \cdot 5(4-7) \\
8 \cdot 0(6-11)^{\star}\end{array}$ & $\begin{array}{l}7 \cdot 0(6-8) \\
8 \cdot 0(7-9)\end{array}$ & $\begin{array}{c}7 \cdot 0(5-8) \\
10 \cdot 0(9-11)^{\star}\end{array}$ & $\begin{array}{l}5 \cdot 0(3-6) \\
6 \cdot 0(4-7)\end{array}$ \\
\hline Peptide B: & & & & \\
\hline $\begin{array}{l}0 \\
4\end{array}$ & $\begin{array}{l}6 \cdot 0(4-8) \\
7 \cdot 0(5-8)\end{array}$ & $\begin{array}{l}8 \cdot 0(7-10) \\
7 \cdot 0(6-8)\end{array}$ & $\begin{array}{l}6.0(5-8) \\
6.0(5-7)\end{array}$ & $\begin{array}{l}6 \cdot 0(4-7) \\
5 \cdot 0(4-7)\end{array}$ \\
\hline Peptide C: & & & & \\
\hline $\begin{array}{c}0 \\
4 \\
\text { Patient } 2\end{array}$ & $\begin{array}{l}6 \cdot 0(5-8) \\
6 \cdot 0(5-7)\end{array}$ & $\begin{array}{l}5 \cdot 5(4-6) \\
5 \cdot 0(4-6)\end{array}$ & $\begin{array}{l}6 \cdot 0(5-7) \\
6 \cdot 0(5-7)\end{array}$ & $\begin{array}{l}5 \cdot 0(4-6) \\
6 \cdot 0(5-7)\end{array}$ \\
\hline Peptide A: & & & & \\
\hline $\begin{array}{l}0 \\
4\end{array}$ & $\begin{array}{l}6 \cdot 0(5-7) \\
9 \cdot 0(8-10)^{\star}\end{array}$ & $\begin{array}{l}5 \cdot 0(4-6) \\
4 \cdot 0(4-6)\end{array}$ & $\begin{array}{l}6 \cdot 0(5-8) \\
8 \cdot 0(6-10)^{\star}\end{array}$ & $\begin{array}{l}5 \cdot 0(4-6) \\
6 \cdot 0(4-6)\end{array}$ \\
\hline $\begin{array}{l}\text { Peptide B: } \\
0 \\
4\end{array}$ & $\begin{array}{l}7 \cdot 0(6-8) \\
7 \cdot 0(5-9)\end{array}$ & $\begin{array}{l}6.0(5-7) \\
6.0(5-8)\end{array}$ & $\begin{array}{l}7 \cdot 0(5-8) \\
7 \cdot 0(6-8)\end{array}$ & $\begin{array}{l}4 \cdot 0(2-5) \\
3 \cdot 5(3-5)\end{array}$ \\
\hline Peptide C: & & & & \\
\hline $\begin{array}{c}0 \\
4 \\
\text { Patient } 3\end{array}$ & $\begin{array}{l}7 \cdot 0(6-8) \\
8 \cdot 0(6-9)\end{array}$ & $\begin{array}{l}5 \cdot 0(4-7) \\
5 \cdot 0(3-7)\end{array}$ & $\begin{array}{l}7 \cdot 0(6-8) \\
8 \cdot 0(6-8)\end{array}$ & $\begin{array}{l}4 \cdot 0(3-5) \\
5 \cdot 0(4-6)\end{array}$ \\
\hline Peptide A: & $6 \cdot 0(5-7)$ & $5 \cdot 0(4-6)$ & $4 \cdot 0(3-5)$ & \\
\hline $\begin{array}{c}4 \\
\text { Peptide B: }\end{array}$ & $8.0(7-9)^{\star}$ & $8 \cdot 0(7-9)^{\star}$ & $\begin{array}{l}4 \cdot 0(3-3) \\
7 \cdot 0(6-8)^{\star}\end{array}$ & $\begin{array}{l}4 \cdot 0(2-4) \\
6 \cdot 0(4-7)^{\star}\end{array}$ \\
\hline & $\begin{array}{l}5 \cdot 0(4-6) \\
6 \cdot 0(4-7)\end{array}$ & $\begin{array}{l}5 \cdot 0(5-7) \\
8 \cdot 0(7-9)^{\star}\end{array}$ & $\begin{array}{l}7 \cdot 0(6-8) \\
8 \cdot 0(7-9)\end{array}$ & $\begin{array}{l}5 \cdot 0(4-6) \\
5 \cdot 0(4-6)\end{array}$ \\
\hline $\begin{array}{l}\text { Peptide C: } \\
0 \\
4\end{array}$ & $\begin{array}{l}4.0(3-5) \\
5 \cdot 0(3-5)\end{array}$ & $\begin{array}{l}5 \cdot 0(5-7) \\
6 \cdot 0(4-7)\end{array}$ & $\begin{array}{l}5 \cdot 0(4-6) \\
5 \cdot 0(4-7)\end{array}$ & $\begin{array}{l}4 \cdot 0(3-7) \\
5 \cdot 0(3-5)\end{array}$ \\
\hline $\begin{array}{l}\text { Patient } 4 \\
\text { Peptide A: }\end{array}$ & & & & \\
\hline $\begin{array}{l}0 \\
4\end{array}$ & $5 \cdot 5(4-7)$ & $5 \cdot 0(4-6)$ & $7 \cdot 0(6-8)$ & $4 \cdot 0(3-5)$ \\
\hline $\begin{array}{c}4 \\
\text { Peptide B: }\end{array}$ & $10 \cdot 0(8-12)^{\star}$ & $8 \cdot 5(7-10)^{\star}$ & $10 \cdot 0(8-11)^{\star}$ & $7 \cdot 0(6-9)^{\star}$ \\
\hline $\begin{array}{l}0 \\
4\end{array}$ & $\begin{array}{l}5 \cdot 0(3-7) \\
5 \cdot 0(4-6)\end{array}$ & $\begin{array}{l}6 \cdot 0(4-7) \\
7 \cdot 0(6-8)\end{array}$ & $\begin{array}{l}5 \cdot 0(4-6) \\
5 \cdot 0(4-6)\end{array}$ & $\begin{array}{l}6 \cdot 0(5-7) \\
6 \cdot 0(5-7)\end{array}$ \\
\hline $\begin{array}{l}\text { Peptide C: } \\
0 \\
4\end{array}$ & $\begin{array}{l}6 \cdot 5(4-8) \\
7 \cdot 0(6-8)\end{array}$ & $\begin{array}{l}5 \cdot 0(4-6) \\
5 \cdot 0(4-6)\end{array}$ & $\begin{array}{l}7 \cdot 0(6-8) \\
6 \cdot 5(5-8)\end{array}$ & $\begin{array}{l}4 \cdot 0(4-6) \\
5 \cdot 0(4-6)\end{array}$ \\
\hline
\end{tabular}

${ }^{\star} \mathrm{p}<0.05$ compared with time 0 .

shows the distribution after four hours. Similar changes were seen with the other cytokine probes. The jejunal mucosa of all the patients studied, contained cells expressing mRNA for IFN $\gamma$, TNF $\alpha$, IL6, and IL2. The positive signal was located mainly in the lamina propria, with little or no signal in the surface epithelium.

\section{Gliadin challenge}

Increased hybridisation signal was seen in the

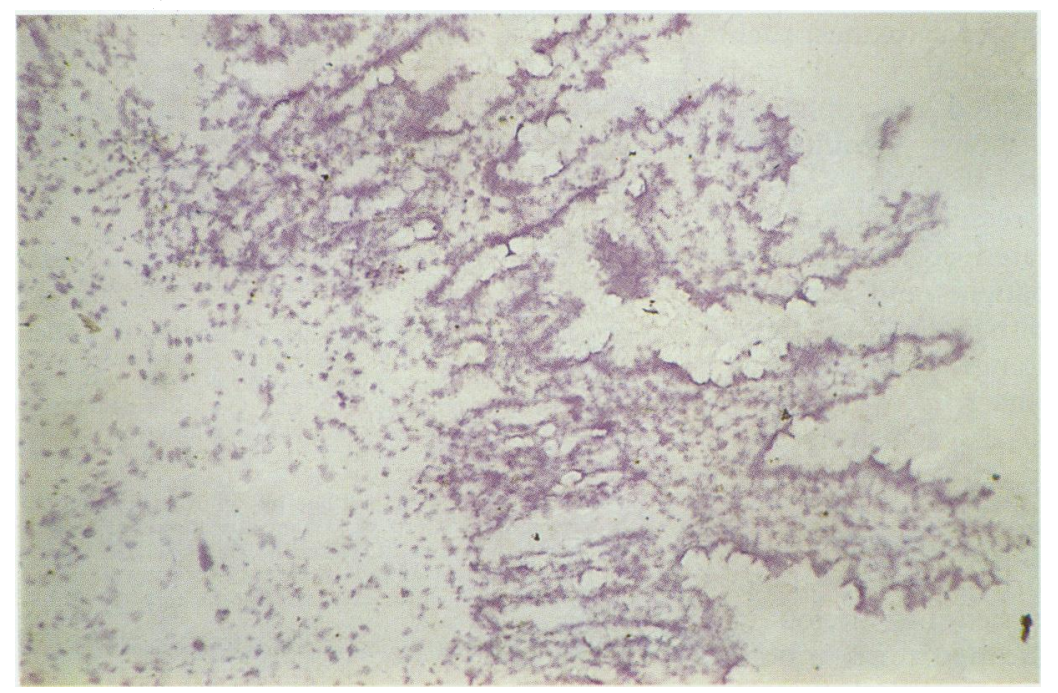

Figure 4: Fejunal biopsy specimen from patient 4, showing absence of hybridisation signal with the sense TNF $\alpha$ probe, used as a negative control ( $\times 200$ magnification). lamina propria of all patients after challenge with 1 gram of gliadin. Figure 3 shows the median value and range of cytokine mRNA expressing cells, in the lamina propria before and at different time intervals after challenge for each of the patients. Two hours after challenge patient 1 showed a significant increase in IFN $\gamma$ mRNA positive cells and patient 2 in IL2 mRNA positive cells only, whereas patients 3 and 4 showed no significant changes in any of the cytokine mRNAs studied.

At four hours after challenge, the number of cells expressing mRNA for IFN $\gamma$, TNF $\alpha$, IL6, and IL2 increased significantly in all four patients. Six hours after the challenge, the number of positive cells of some cytokines, such as TNF $\alpha$ in patients 3 and 4 and IL 2 in patients 1 and 3 , returned to prechallenge values.

\section{Peptide challenge}

The number of cells expressing cytokine mRNA was also measured in the lamina propria of each patient, before and four hours after challenge with each of the three oligopeptides studied (Table III).

After challenge with peptide $\mathrm{A}$, patients 3 and 4 showed a significant increase in the number of cells expressing mRNA for IFN $\gamma$, $\mathrm{TNF} \alpha$, IL2, and IL6, but patients 1 and 2 showed a significant increase in IFN $\gamma$ and IL6 mRNA expressing cells only.

Challenge with peptide $B$ resulted in increased numbers of TNF $\alpha$ mRNA expressing cells in the lamina propria of patient 3 only, but caused no changes in the other patients.

No response was seen in any of the patients with peptide $\mathrm{C}$.

\section{Controls}

Figure 4 shows the typical appearance of a section of jejunal mucosa, four hours after gliadin challenge, after hybridisation with the TNF $\alpha$ sense probe. All sections that were hybridised with the IFN $\gamma$, IL6, and IL2 sense probes showed no hybridisation signal. None of the RNase treated sections showed any positive signal, showing that hybridisation was indeed on mRNA.

\section{Discussion}

The jejunal mucosa of treated coeliac patients contains cells expressing mRNA for the cytokines IFN $\gamma$, TNF $\alpha$, IL6, and IL2, and these are found mainly in the lamina propria. A number of similar studies have shown the presence of cytokines and hence activated immunocompetent cells in normal intestinal mucosa. ${ }^{171920}$

Previous studies have shown increased expression of IFN $\gamma$ mRNA in untreated coeliac patients compared with treated patients and controls and suggests an association between the observed morphological changes and mucosal T cell activation. ${ }^{17}$ IFN $\gamma$ in combination with $\mathrm{TNF} \alpha$ has been shown to increase expression of $\mathrm{MHC}$ class $\mathrm{I}$ and $\mathrm{II}^{21}$ and adhesion molecules within intestinal 
tissue. ${ }^{22}$ Both cytokines can destroy target tissues of known autoimmune disease ${ }^{23}$ and also reduce the epithelial barrier function of the human colon carcinoma cell line HT29. ${ }^{24} 25$

The results of this study complement our previous findings, ${ }^{8}$ by showing increased cytokine expression in the lamina propria of treated coeliac patients, four hours after gliadin challenge, which coincides with significant histological changes in the small intestinal mucosa of these patients. It was shown that the synthetic oligopeptide corresponding to residues $31-49$ of A-gliadin (peptide A) displays in vivo toxicity in these patients with treated coeliac disease. We have now shown that the lamina propria of the same patients contained increased numbers of cells expressing cytokine mRNA in response to peptide A. Other studies have shown that peptide $A$ is recognised by gliadin specific $T$ cell clones when presented by HLA-DQ2 molecules, ${ }^{26}$ which is present in over $95 \%$ of patients with coeliac disease. ${ }^{27}$ Therefore, taken together these findings provide strong support for the role of peptide $A$ as a coeliac toxic fragment of A-gliadin.

An association between histological changes and cytokine expression was seen in one of four patients studied after challenge with peptide $B$. In this patient the peptide caused a significant reduction both in villous height to crypt depth ratio and enterocyte height, but not an increase in intraepithelial lymphocyte numbers. ${ }^{8}$ These changes were associated with increased numbers of cells expressing $\mathrm{TNF} \alpha \mathrm{mRNA}$. No changes in cytokine expression were seen in any of the patients after challenge with peptide $\mathrm{C}$, confirming our previous findings of no histological change and no increase in intraepithelial lymphocyte counts in these same patients after challenge with this peptide.

We suggest that toxic wheat peptides, such as peptide $\mathrm{A}$ are absorbed across the small intestinal epithelium, bound to HLA class II molecules, and presented by macrophages in the lamina propria to antigen specific $\mathrm{CD}^{+} \mathrm{T}$ cells. Increased activation of immunocompetent cells in the small intestinal lamina propria leads to increased synthesis of cytokines, such as IFN $\gamma$ and IL 2 by activated T cells and TNF $\alpha$ and IL 6 by activated macrophages. Previous studies have shown significantly greater numbers of IL6, IL2, and TNF $\alpha$ mRNA and protein expressing cells in the lamina propria of untreated coeliac patients compared with treated patients and controls, but low values in the epithelium of all three groups. ${ }^{28} 29$ Our results do not, however, agree with the findings of Shirota et al, which have suggested that IL6 mRNA is exclusively produced in the epithelium in coeliac disease mucosa. ${ }^{30}$

It is possible that the production of these cytokines can either cause direct damage to the mucosa or lead to increased production of other inflammatory or toxic mediators, or both that are responsible for the histological changes in coeliac disease. An interesting finding was that, after challenge with peptide $A$, the number of IFNy mRNA expressing cells increased in all four patients studied. This could suggest that this cytokine is primarily produced during the immune response acting to propogate the $\mathrm{T}$ cell mediated immune response and the release of other inflammatory cytokines. The hypothesis that cytokines are capable of causing direct tissue damage could be confirmed by studying their effect on epithelial differentiation and proliferation in human jejunum organ culture. Recent data using such a system have shown that supernatants from gliadin activated HLA DQ2 restricted $\mathrm{T}$ lymphocyte clones cause epithelial cell toxicity similar to that seen in untreated coeliac mucosa and this effect may be blocked by anti-IFN $\gamma$ antibodies. ${ }^{31}$

Our findings suggest that the expression of cytokine mRNA by lamina propria cells may reflect a process of cellular activation during the development of coeliac disease. It is possible that understanding the production of cytokines and its regulation within the small intestinal mucosa may lead to the recognition of new approaches to treatment of coeliac disease.

The authors wish to thank $\mathrm{Mr} \mathrm{J} M$ Nelufer for technical assistance. Grant support was provided by the St Thomas' research (endowments) committee, the Nutricia research fund, $A B$ Semper, and the Jean Shanks research foundation.

1 Marsh MN. The morphology and immunopathology of the jejunal lesion in gluten-sensitivity. Eur $\mathcal{f}$ Gastroentero Hepatol 1991; 3: 163-8.

2 Marsh MN. Mucosal pathology in gluten sensitivity. In: Marsh MN, ed. Coeliac disease. Oxford: Blackwell Scientific, 1992: 136-91

3 Spencer J, MacDonald T, Walker-Smith J, Ciclitira $\mathrm{P}$ Isaacson $P$. Changes in intra-epithelial lymphocyte subpopulations in coeliac disease and enteropathy associated T-cell lymphoma (malignant histiocytosis of the intestine). Gut 1989; 30: 339-46.

4 Brandtzaeg P, Halstensen T, Kett K, Kracci P, Kvale D, Rognum TO, et al. Immunobiology and immunopathology of human gut mucosa: humoral immunity and intraepithelial lymphocytes. Gastroenterology 1989; 97: 1562-84.

5 Frazer A, Fletcher R, Ross C, Shaw B, Sammons H, Schneider R. Gluten-induced enteropathy. The effect of partially digested gluten. Lancet 1959 ; ii: $252-5$.

6 de Ritis G, Auricchio S, Jones H, Lew E-L, Bernardin J, Kasarda D. In vitro (organ culture) studies of the toxicity of specific A-gliadin peptides in coeliac disease. Gastroenterology 1988; 94: 41-9.

7 Tatham A, Marsh M, Wieser H, Shewry P. Conformational studies of peptides corresponding to the coeliac-activating studies of peptides corresponding to the coeliac-activating

8 Sturgess R, Day P, Ellis H, Lundin KE, Gjertsen HA, Sturgess R, Day P, Ellis H, Lundin KE, Gjertsen HA,
Kontakoy M, et al. Wheat peptide challenge in coeliac Kontakoy $M$, et al. Wheat peptide
disease. Lancet 1994; 343: 758-61.

9 Mantzaris GJ, Jewell DP. In vitro toxicity of a synthetic dodecapeptide from A-gliadin in patients with coeliac disease. Scand f Gastroenterol 1991; 26: 392-8.

10 Halstensen T, Scott H, Fausa O, Brandtzaeg P. Gluten stimulation of coeliac mucosa in vitro induces activation (CD25) of lamina propria CD4+ $T$ cells and macrophages but no crypt-cell hyperplasia. Scand $f$ Immunol 1993; 38: 581-90.

11 Murch S, Braegger C, Walker-Smith J, MacDonald T. Location of tumour necrosis factor $\alpha$ by immunohistochemistry in chronic inflammatory bowel disease. Gut chemistry in chromic

12 Jones S, Trejdosiewicz L, Banks R, Howdle PD, Axon ATR, Dixon MF, et al. Expression of interleukin-6 by ATR, Dixon MF, et al. Expression of interleukin-6 by

13 Brese E, Braegger C, Corrigan C, Walker-Smith J, MacDonald $\mathrm{T}$. Interleukin-2 and interferon-secreting $T$ cells in normal and diseased human intestinal mucosa. Immunology 1993; 78: 127-31.

14 Reinecker H, Steffen M, Witthoeft T, Pflueger I, Scheriber $S$, MacDermott RP, et al. Enhanced secretion of tumour necrosis factor-alpha, IL-6, and IL-1 $\beta$ by isolated lamina propria mononuclear cells from patients with ulcerative colitis and Crohn's disease. Clin Exp Immunol 1993; 94: 174-81.

15 Meeuwisse GW. Diagnostic criteria in coeliac disease (European Society of Paediatric Gastroenterology). Acta Paediatr Scand 1970; 59: 461-3.

16 Sambrook J, Fritsch E, Maniatis T. Molecular cloning: $a$ laboratory manual. New York: Cold Spring Harbor Laboratory Press, 1989: 7.4. 
17 Kontakou M, Sturgess R, Przemioslo R, Limb G, Nelufer J, Ciclitira $P$. Detection of interferon-gamma mRNA in the mucosa of patients with coeliac disease by in situ hybridisation. Gut 1994; 35: 1037-41.

18 Hamid Q, Azzawi M, Ying S, Moqbel R, Wardlaw AJ, Corrigan CJ, et al. Expression of mRNA for interleukin-5 in mucosal bronchial biopsies from asthma. $\mathcal{f}$ Clin Invest 1991; 87: 154

19 MacDonald T, Hutchings P, Choy M, Murch S, Cooke A. Tumour necrosis factor-alpha and interferon-gamma production measured at the single cell level in normal and inflamed human intestine. Clin Exp Immunol 1990; 81: 301-5.

20 Al-Dawoud A, Nakshabendi I, Foulis A, McMowat A. Immunohistochemical analysis of mucosal gamma-interferon production in coeliac disease. Gut 1992; 33: 1482-6.

21 Kvale D, Brandtzaeg P, Lovhaug D. Up-regulation of the expression of secretory component and HLA molecules in a human colonic cell line by tumour necrosis factor- $\alpha$ and amma interferon. Scand f Immunol 1988; 28: 351-7.

22 Doukas J, Pober J, IFN-gamma enhances endothelial activation induced by tumour necrosis factor but not IL-1. $\mathcal{F}$ vation induced by tumour necr

23 Cambell I, Iscaro A, Harrison L, IFN $\gamma$ and tumour necrosis factor $\alpha$ cytotoxicity to murine islets of Langerhans. $\mathcal{F}$ Immunol 1988; 141: 2325-31.

24 Deem R, Shanahan F, Targan S. Triggered human mucosal $T$ cells release tumour necrosis factor-alpha and interferon-gamma which kill human colonic epithelial cells.
Clin Exp Immunol 1991; 83: 79-84.

25 Hiribarren A, Heyman M, L'Helgouac'h A, Dejeux J. Effect of cytokines on the epithelial function of the human colon carcinoma cell line HT29 cl 19A. Gut 1993; 34: 616-20. 26 Gjertsen H, Lundin K, Sollid L, Eriksen J, Thorsby E. $T$-cells recognize a peptide derived from $\alpha$-gliadin presented by the coeliac disease associated HLA-DQ $\left(\alpha 1^{\star} 0501, \beta 1^{\star} 0201\right)$ heterodimer. Hum Immunol 1994; 39: 243-52.

27 Spurkland A, Sollid L, Ronningen K, Bosnes V, Ek J, Vartdal F, et al. Susceptibility to develop celiac disease is primarily associated with HLA-DQ alleles. Hum Immunol 1990; 29: 157-65.

28 Przemioslo R, Kontakou M, Nobili V, Sturgess R, Nelufer G, Ciclitira PJ. Interleukin-6 and tumour necrosis factoralpha in coeliac disease mucosa detected by immunohistochemistry and in situ-hybridisation. Gut 1993; 34 (suppl 4): S24.

29 Kontakou M, Przemioslo R, Sturgess R, Limb G, Ciclitira $P$. Expression fo TNF $\alpha$, IL-6 and IL-2 mRNA in the jejunum of patients with coeliac disease. Scand $\mathcal{f}$ Gastroenterol (in press).

30 Shirota K, LeDuy I, Yuan S, Jothy S. Interleukin 6 and its receptor are expressed in human intestinal epithelial cells. Virchows Archiv (B) 1990; 58: 307-8.

31 Przemioslo R, Lundin K, Sollid L, Ciclitira P. Histological changes in duodenal mucosa produced by soluble mediators from gliadin sensitive T-cells. Gut 1994; 35 (suppl 2): S29. 